$\underline{\text { Research Article }}$

\title{
Prevalence of multidrug resistance genes in Escherichia coli isolates from patients attending four hospitals in Minna, Nigeria
}

\author{
FP Oloruntoba ${ }^{1}$, NU Adabara $^{1}$, AS Adedeji ${ }^{1}$, FA Kuta $^{1}$, CM Ezeonu ${ }^{1}$ \\ Sri Lankan Journal of Infectious Diseases 2020 Vol.10 (1):53-64 \\ DOI: http://dx.doi.org/10.4038/sljid.v10i1.8269
}

\begin{abstract}
Objectives: This study determined the prevalence, antibiotic susceptibility and resistance genes among multidrug resistant Escherichia coli isolates from diarrheic patients in four hospitals within Minna, Nigeria.
\end{abstract}

Methods: Stool samples from one hundred and seven (107) diarrheic patients were collected and analysed to check for $E$. coli using spread plate techniques. The resistance pattern of the E. coli isolates to ten (10) antibiotics using disc diffusion techniques was determined. Five isolates with multidrug resistant index $\geq 0.5$ were screened for antibacterial resistant genes (Tn3bla, GyrA, ParC, aadA2 and Sul1) using polymerase chain reaction.

Results: Seventy (70) samples representing $65.4 \%$ were E. coli positive while fifty-five (55) were resistant to at least one antibiotic. The highest level of resistance was against ampicillin $(38.57 \%)$ while the least was against cefalexin (4.29\%). Multidrug resistant isolates were $58.7 \%$ (41/70), while $28.6 \%$ (20/70) were resistant to three or more antibiotics. The result of the molecular characterization identified the five multidrug resistant isolates to be $E$. coli strain RAD34, E. coli strain CUSMBN2, E. coli strain CAU3471, and E. coli strain BYPFP. Tn3bla/GyrA/ParC resistant genes were detected in all the five isolates. E. coli isolate RAD34, E. coli strain CUSMBN2, E. coli strain CAU3471 and E. coli strain BYPFP possessed Sul1 gene. However, E. coli strain BYPFP, E. coli strain CAU3471 and E. coli strain CUSMBN2 had aadA2 gene.

Conclusion: The result of this study established the active circulation of Tn3bla, GyrA, ParC, aadA2 and Sull resistant genes among E. coli in the study area.

Keywords: Diarrhoea, Specific primers, Multidrug resistance genes

\footnotetext{
${ }^{1}$ Department of Microbiology, School of Life Sciences, Federal University of Technology, Minna, Niger State, Nigeria

Address for correspondence: AS Adedeji, Department of Microbiology, School of Life Sciences, Federal University of Technology, Minna, Niger State, Nigeria. Telephone: +2348135445842

Email: sabdulameen@futminna.edu.ng (iD https://orcid.org/0000-0003-4885-4315
}

Received 16 October 2019 and revised version accepted 18 February 2020

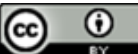

This an open-access article distributed under the terms of the Creative Commons Attribution License, which permits unrestricted use, distribution, and reproduction in any medium, provided the original author and source are credited. 


\section{Introduction}

Antibiotics continue to play a crucial role in the treatment of bacterial diseases since they were first discovered in 1929. ${ }^{1}$ However, the emergence of resistance, which was first reported in $1940,{ }^{1}$ and the continuing evolution of resistance even to newer drugs, remains a great challenge for control of both bacterial diseases as well as many other diseases that affect mankind.

Drug resistance among bacteria that cause either community acquired infections or hospital acquired infections has increased tremendously in the last few decades and is currently generating serious concern within the global health community. ${ }^{2} E$. coli have been identified as one of the most important multidrug resistant bacteria by the World Health Organization's (WHO) report of priority pathogens, because of their distinct ability to resist antibiotics as well as transfer the mechanism to other bacteria. ${ }^{3}$ They are the most common cause of urinary tract infections (UTIs) in humans ${ }^{4}$, as well as a leading cause of food-borne infections primarily due to the Shiga-toxin producing strains..$^{5-7}$

The problem of antibiotic resistance among bacteria globally and particularly in Nigeria calls for urgent attention. ${ }^{2,8}$ It was reported by Larsson et al. ${ }^{8}$ that bacterial infections alone accounted for as much as $45 \%$ of death witnessed at the turn of the century. A number of mechanisms have been identified as being involved in bacterial resistance to certain antibiotics and this knowledge is already being translated into positive action to improve our antibiotic arsenal against resistance. One such example is the conjugation of clavulanic acid with $\beta$-lactams to overcome the hydrolytic activity of $\beta$-lactamase enzymes utilized by bacteria against $\beta$-lactam drugs. ${ }^{9}$

To effectively prevent the spread of antibiotic resistance and/or treat persistent infections, the mechanism of resistance as well as other molecular epidemiologic information of the causative agent(s) are required, hence the need for this study.

\section{Methods}

\section{Study area}

Minna is the capital of Niger State, Nigeria. It is situated on Latitude $9.61 \mathrm{~N}$ and Longitude 6.56 $\mathrm{E}$ at an elevation of $299 \mathrm{~m}$ above sea level. It is bordered to the North by Sokoto State, West by Kebbi State, and South by Kogi and South-West by Kwara State. Niger State has a common boundary with the Republic of Benin along New Bussa, Agwara and Wushishi Local Government Area. Samples were collected from the microbiology laboratories of selected hospitals in Minna, which included the Nigeria General hospital (GH), Ibrahim Babangida Specialist hospital (IBBSH), Standard Hospital (SH) and Top Medical Hospital (TMH) as shown in Figure 1. 


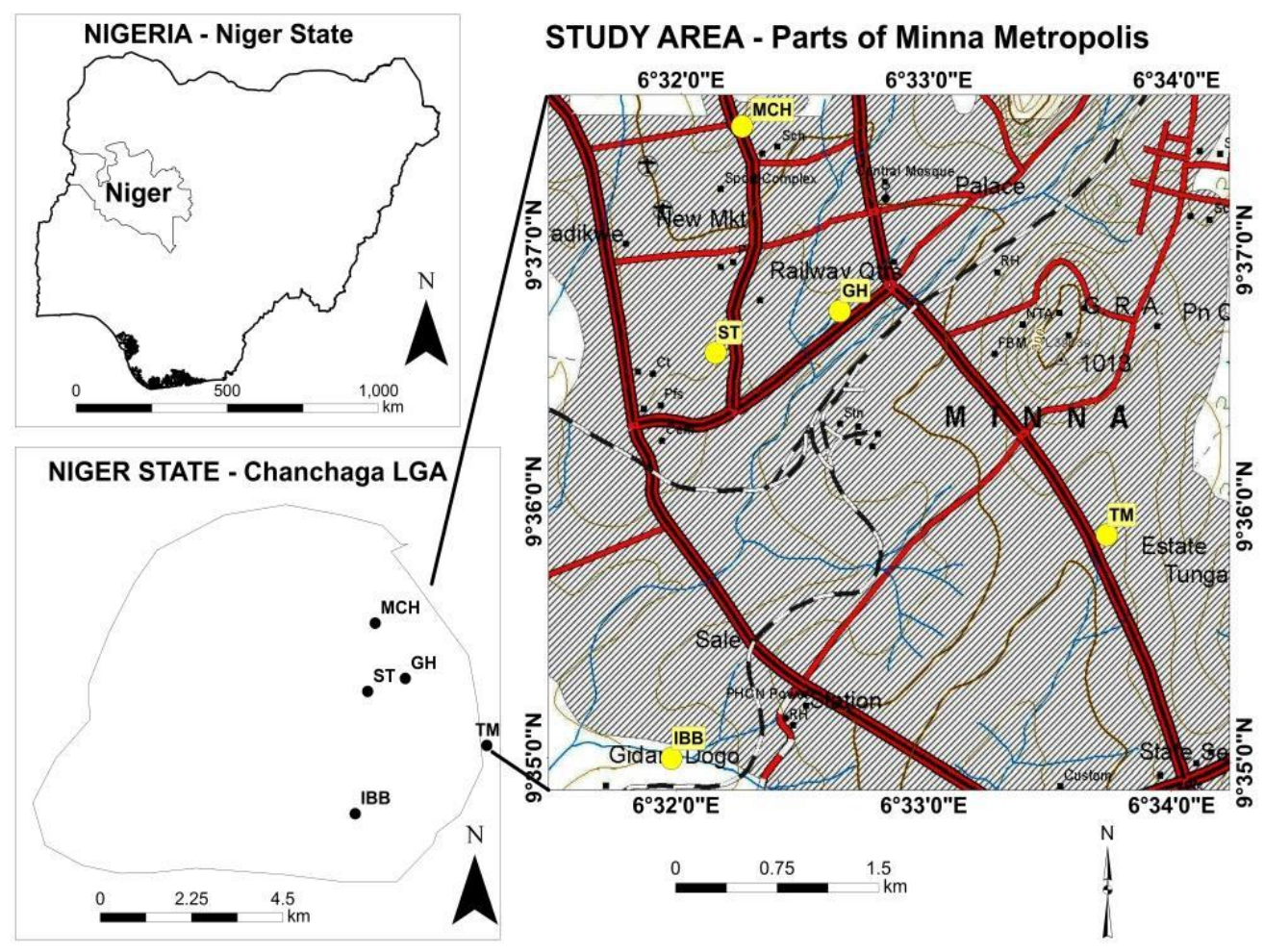

Figure 1: Study area and distribution of hospitals included in the study

$\mathrm{GH}=$ General Hospital, IBBSH= IBB Specialist Hospital, SH=Standard Hospital, TMH= Top Medical Hospital.

\section{Sample collection}

Stool samples from one hundred and seven (107) diarrheic patients were collected from patients attending four hospitals in Minna, Nigeria between February and June 2017. Ethical clearance was obtained from the research and ethics committee of the Niger State Hospitals Management Board for the study. Sixty (60) stool samples from GH, twenty-five (25) from IBBSH, fifteen (15) from SH and seven (7) from TMH were included in the study. Patients within the age range of 10-65 years who were attendees of the selected hospitals and consented to take part were included.

\section{Isolation and Identification of Escherichia coli}

An aliquot of stool sample was inoculated into $10 \mathrm{~mL}$ sterile peptone water and incubated for 8 hours at $37{ }^{\circ} \mathrm{C}$. A loopful from the above was streaked onto Eosin Methylene Blue (EMB) agar plates and incubated at $37{ }^{\circ} \mathrm{C}$ for 18 hours. Colonies (one per plate) that showed characteristic green metallic sheen on EMB agar were further sub-cultured onto nutrient agar slants for further analysis. The pure isolates obtained were identified and characterized based on their cultural (colony) characteristics, Gram stain and biochemical properties. ${ }^{10}$

\section{Antimicrobial susceptibility test}

Kirby Bauer's disc diffusion technique was used for antimicrobial susceptibility testing. ${ }^{10}$ The 
results were interpreted using Clinical and Laboratory Standards Institute (CLSI) guidelines (2015). ${ }^{11}$ Briefly, individual colonies were suspended in normal saline to 0.5 McFarland standard. Using a sterile swab, the suspensions was inoculated on Muller Hinton agar and incubated at

$37{ }^{\circ} \mathrm{C}$ for 18 hours. Commercially available antibiotic (streptomycin $(10 \mu \mathrm{g})$, ampicillin $(10 \mu \mathrm{g})$, co-trimoxazole $(23.75 \mu \mathrm{g})$, erythromycin $(15 \mu \mathrm{g})$, ofloxacin $(5 \mu \mathrm{g})$, cefalexin $(30 \mu \mathrm{g})$, ciprofloxacin $(5 \mu \mathrm{g})$, amoxicillin/clavulanic acid $(10 \mu \mathrm{g})$, gentamicin $(15 \mu \mathrm{g}))$ discs of the drugs commonly used for treatment of Gram-negative bacterial infections were tested. The zone of inhibition was measured and used to classify the organisms as susceptible, intermediate or resistant to a specific antibiotic. ${ }^{11}$

Multidrug-resistant (MDR) E. coli isolates were defined by resistance to $\geq 1$ agent in $\geq 3$ antimicrobial classes. Five MDR $E$. coli isolates resistant to $\geq 3$ antimicrobials, with at least one antibiotic per antimicrobial group were selected for molecular identification and antibiotic resistance gene detection using PCR with primers specific for E. coli and antibiotic resistance genes (Tn3bla, GyrA, aadA2 and Sull).

Multiple Antibiotic Resistance Index (MARI) in respect to a single isolate defined as a/b, where "a" represents the number of antibiotics to which the isolate was resistant and " $b$ " represents the number of antibiotics to which the isolate was exposed, was also calculated. ${ }^{12}$

\section{Molecular characterization of multidrug resistant $E$. coli isolates}

The molecular characterization of five $E$. coli isolates with multidrug resistant index $\geq 0.5$ were confirmed using PCR with primers specific for E. coli. DNA was extracted by the protocol described by Zhang et al. ${ }^{3}$ The integrity of the extracted DNA was checked on a $1 \%$ agarose gel to confirm extraction. ${ }^{3}$ The ribosomal RNA primer (16SF: GTGCCAGCAGCCGCGCTAA and 16SR: AGACCCGGGAACGTATTCAC) used for the molecular characterisation of the E. coli isolates was obtained from the International Institute of Tropical Agriculture (IITA), Ibadan, Nigeria. PCR was carried out on a GeneAmp 9700 PCR System Thermalcycler (Applied Biosystem Inc., USA) following the protocol described by Luo et al. ${ }^{13}$

The PCR product was loaded on $1.5 \%$ agarose gel. The ladder used was Invitrogen ${ }^{\mathrm{TM}} 1 \mathrm{~Kb}$ Plus DNA Ladder. The expected base pair of the amplicon was 1500bp. The amplified fragments were sequenced using a Genetic Analyzer 3130xl sequencer (Applied Biosystems). The sequencing kit used was that of BigDye terminator v3.1 cycle sequencing kit. Bio- Edit software and molecular evolutionary genetics analysis (MEGA 6) were used for all genetic analysis. Identities and accession numbers of the $E$. coli isolates were determined by Basic Local Alignment Search Tool (BLAST) from the GENE BANK at www.ncbi.nlm.nih.gov. ${ }^{14}$

\section{Detection of antibiotic resistance genes}

PCR technique using antibiotic resistance genes specific primers was used to screen five (5) isolates with multidrug resistance index $\geq 0.5$ for the presence of five resistance genes, namely th3bla, gyrac, aadA2 and sull in their template DNA. ${ }^{6}$ The primers and their sequences are shown in Table 1. 
Table 1: Primers used for identifying the multidrug resistance genes of $E$. coli isolates

\begin{tabular}{|c|c|c|c|}
\hline Group of antibiotics & Resistance genes & Product size & Primer sequence \\
\hline \multirow[t]{2}{*}{ Penicillin } & Tn3bla & $800 \mathrm{bp}$ & Forward 5'-CGCGGAACCCCTATTTGTTT-3' \\
\hline & & & Backward 5'-GGTCTGACAGTTACCAATG-3' \\
\hline Quinolone & gyrA & $200 \mathrm{bp}$ & Forward 5'-ACGTACTAGGCAATGACTGG-3' \\
\hline \multirow[t]{2}{*}{ Aminoglycoside } & $\operatorname{aadA2}$ & $533 \mathrm{pb}$ & $\begin{array}{l}\text { Backward 5'-AGAAGTCGCCGTCGATAGAAC-3' } \\
\text { Forward 5'-ATTTGCTGGTTACGGTGACC-3' }\end{array}$ \\
\hline & & & Backward 5'-CTTCAAGTATGACGGGCTGA-3' \\
\hline \multirow[t]{2}{*}{ Sulfonamide } & Sull & 400bp & Forward 5'-TGAGATCAGACGTATTGCGC-3' \\
\hline & & & Backward 5'-TTGAAGGTTCGACAGCACGT-3' \\
\hline \multirow[t]{2}{*}{ Quinolone } & $\operatorname{parC}$ & $287 \mathrm{bp}$ & Forward 5'-GCCTTGCGCTACATGAATTT-3' \\
\hline & & & Backward 5'-ACCATCAACCAGCGGATAAC-3' \\
\hline
\end{tabular}

Reaction cocktail used for all PCR per primer set included (reagent volume $\mu \mathrm{l}$ ) - 10X PCR SYBR

green buffer (2.5), $25 \mathrm{mM} \mathrm{MgCl} 2$ (1.0), $5 \mathrm{pMol}$ forward primer (1.0), $5 \mathrm{pMol}$ reverse primer (1.0), DMSO (1.0), 2.5Mm DNTPs (2.0), Taq 5u/uL (0.1), made up to 22 with sterile distilled water to which $3 \mu$ l template was added. The amplicon from the PCR was loaded on $1.5 \%$ agarose gel. The bands that appeared were compared with that of the ladder and the observation were recorded.

\section{Results}

Distribution of $E$. coli isolated from the four hospitals

The number of positive samples for E. coli is presented in Table 2. The highest number of E.coli isolates $(\mathrm{n}=45 ; 64.3 \%)$ were from $\mathrm{GH}$, while only 3 (4.3\%) were from TMH.

Table 2: Distribution of $E$. coli isolated from the 4 hospitals

\begin{tabular}{|c|c|c|c|c|}
\hline \multirow[b]{2}{*}{ Hospital } & \multirow{2}{*}{$\begin{array}{l}\text { Samples } \\
\text { collected }\end{array}$} & \multirow[t]{2}{*}{ No } & \multicolumn{2}{|c|}{ E. coli isolates. } \\
\hline & & & $\begin{array}{c}\%+v e \\
\text { for each hospital }\end{array}$ & $\%$ of total no of $E$. coli \\
\hline General & 60 & 45 & 75.0 & 64.3 \\
\hline Ibrahim Babangida & 25 & 15 & 60.0 & 21.4 \\
\hline Standard & 15 & 7 & 46.7 & 10.0 \\
\hline Top Medical Hospitals & 7 & 3 & 42.9 & 4.3 \\
\hline Total & 107 & 70 & & 100 \\
\hline
\end{tabular}




\section{Antibiotics susceptibility screening}

The isolates showed a varied pattern of susceptibility and resistance as shown in Table 3 . The highest resistance $(38.6 \%)$ was against ampicillin while the least $(4.3 \%)$ was recorded against cefalexin.

Table 3: Antibiotics Susceptibility Screening

\begin{tabular}{|l|c|c|c|c|c|c|c|}
\hline Antibiotics & $\boldsymbol{\mu g}$ & $\begin{array}{c}\text { No. } \\
\text { resistance }\end{array}$ & $\mathbf{\%}$ & $\begin{array}{c}\text { No. } \\
\text { intermediate }\end{array}$ & $\mathbf{\%}$ & $\begin{array}{c}\text { No. } \\
\text { Susceptible }\end{array}$ & $\%$ \\
\hline S & 10 & 12 & 17.1 & 17 & 24.3 & 41 & 58.6 \\
\hline PN & 10 & 27 & 38.6 & 23 & 32.9 & 20 & 28.6 \\
\hline SXT & 23.75 & 19 & 27.2 & 35 & 50.0 & 16 & 22.9 \\
\hline E & 15 & 6 & 8.6 & 22 & 31.4 & 42 & 60.0 \\
\hline OFX & 5 & 22 & 31.4 & 22 & 31.4 & 26 & 37.1 \\
\hline PEF & 5 & 9 & 12.9 & 8 & 11.4 & 53 & 75.7 \\
\hline CPX & 5 & 6 & 8.6 & 4 & 5.7 & 60 & 85.7 \\
\hline AU & 10 & 22 & 31.4 & 28 & 40.0 & 20 & 28.6 \\
\hline CEP & 30 & 3 & 4.3 & 23 & 32.9 & 44 & 62.9 \\
\hline CN & 15 & 8 & 11.4 & 10 & 27.1 & 43 & 61.4 \\
\hline
\end{tabular}

S (streptomycin), PN (ampicillin), SXT (cotrimoxazole), E (erythromycin), OFX (ofloxacin), PEF (perfloxacin), CPX (ciprofloxacin), AU (Amoxycillin/clavulanic acid), CEP (cefalexin), CN (gentamicin)

Antibiotic susceptibility profile of the isolated $E$. coli

Of the seventy isolated $E$. coli strains, $78.6 \%(55 / 70)$ were resistant to at least one antibiotic (Table

4). MDR E. coli isolates accounted for $58.7 \%$ (41/70) of the isolated strains while $28.6 \%$ (20/70)

were resistant to three or more antibiotics. The five isolates (H, B, E 3 and A) with multidrug resistant index $\geq 0.5$ were selected for further molecular analysis. 
Table 4: Single and multidrug resistance pattern in $E$. coli isolates

\begin{tabular}{|c|c|c|c|c|c|c|c|c|c|c|c|}
\hline ID & $\mathrm{RP}$ & MDRI & ID & $\mathrm{RP}$ & MDRI & ID & $\mathrm{RP}$ & MDRI & ID & $\mathrm{RP}$ & MDRI \\
\hline Q & OFX & 0.1 & I & $\mathrm{S} / \mathrm{PN}$ & 0.2 & $2 \mathrm{YS}$ & $\mathrm{PN} / \mathrm{AU}$ & 0.2 & M & PN/SXT/CEP & 0.3 \\
\hline $\mathrm{Z}$ & PN & 0.1 & BI & OFX/AU & 0.2 & $\mathrm{U} 30$ & $\mathrm{~S} / \mathrm{PN}$ & 0.2 & $\mathrm{~S} 12$ & S/PN/PEF & 0.3 \\
\hline 18 & $\mathrm{CN}$ & 0.1 & 80 & $\mathrm{PN} / \mathrm{E}$ & 0.2 & S37 & S/OFX & 0.2 & $17 \mathrm{C}$ & PN/SXT/AU & 0.3 \\
\hline 44 & $\mathrm{E}$ & 0.1 & $\mathrm{~S} 40$ & E/OFX & 0.2 & $\mathrm{~S}$ & PN/PEF & 0.2 & $\mathrm{Ve}$ & S/PN/SXT & 0.3 \\
\hline 32 & PN & 0.1 & 38 & $\mathrm{~S} / \mathrm{E}$ & 0.2 & 78 & PN/SXT/AU & 0.3 & $8 \mathrm{C}$ & $\mathrm{PN} / \mathrm{SXT} / \mathrm{CPX} / \mathrm{AU}$ & 0.4 \\
\hline 69 & $S$ & 0.1 & $\mathrm{C} 13$ & PN/AU & 0.2 & 70 & $\mathrm{PEF} / \mathrm{AU} / \mathrm{CN}$ & 0.3 & A & $\mathrm{PN} / \mathrm{SXT} / \mathrm{OFX} / \mathrm{AU} / \mathrm{CN}$ & 0.5 \\
\hline $\mathrm{Li}$ & OFX & 0.1 & $53 \mathrm{~A}$ & SXT/OFX & 0.2 & 52 & SXT/PEF/AU & 0.3 & $\mathrm{H}$ & PN/SXT/OFX/AU/CEP & 0.5 \\
\hline S11 & OFX & 0.1 & E1 & $\mathrm{S} / \mathrm{PN}$ & 0.2 & 34 & OFX/CPX/AU & 0.3 & 3 & SXT/PEF/CPX/AU/CN & 0.5 \\
\hline $\mathrm{N}$ & OFX & 0.1 & $\mathrm{~L}$ & S/OFX & 0.2 & S14 & OFX/PEF/CPX & 0.3 & B & PN/SXT/OFX/PEF/AU/CEP & 0.6 \\
\hline $\mathrm{L} 2$ & OFX & 0.1 & $9 \mathrm{~B} 3$ & СРX/CEP & 0.2 & 31 & $\mathrm{PN} / \mathrm{SXT} / \mathrm{E}$ & 0.3 & $\mathrm{E}$ & $\mathrm{PN} / \mathrm{SXT} / \mathrm{PEF} / \mathrm{CPX} / \mathrm{AU} / \mathrm{CN}$ & 0.6 \\
\hline 9 & $\mathrm{PN}$ & 0.1 & E8 & $\mathrm{R} / \mathrm{AU}$ & 0.2 & TS & SXT/OFX/AU & 0.3 & \multirow{4}{*}{\multicolumn{3}{|c|}{$\begin{array}{l}\text { RP } \quad-\text { Resistance Profile } \\
\text { MDRI - Multidrug resistance index }\end{array}$}} \\
\hline G & $\mathrm{PN}$ & 0.1 & $4 \mathrm{~T}$ & S/AU & 0.2 & $\mathrm{P}$ & S/PN/OFX & 0.3 & & & \\
\hline S10 & $\mathrm{CN}$ & 0.1 & 28 & PN/AU & 0.2 & $\mathrm{~F}$ & PN/SXT/AU & 0.3 & & & \\
\hline 32 & OFX & 0.1 & E2 & $\mathrm{PN} / \mathrm{E}$ & 0.2 & F8 & PN/SXT/AU & 0.3 & & & \\
\hline
\end{tabular}

S (streptomycin), PN (ampicillin), SXT (cotrimoxazole), E (erythromycin), OFX (ofloxacin), PEF (perfloxacin), CPX (ciprofloxacin), AU (amoxycillin/clavulanic acid ), CEP (cefalexin), CN (gentamicin),

\section{Molecular characterization of five (5) $E$. coli isolates}

The result of the $16 \mathrm{~S}$ rRNA gene sequencing of the five (5) isolates with multidrug resistance index $\geq 0.5$ isolates revealed them to be E. coli strain RAD34 (n=2), E. coli strain CUSMBN2, $E$. coli strain CAU3471, and E. coli strain BYPFP.

\section{Antibiotic resistance gene presents in the $E$. coli isolates}

PCR result using extracted DNA from isolate A indicated the presence of Tn3bla, GyrA and ParC gene whereas the presence of aadA2 and Sull were absent. Similarly, isolates B, H and E were positive for the genesTn3bla, GyrA, ParC, aadA2 and Sull with the presence of 800 bp, $200 \mathrm{bp}, 287 \mathrm{bp}, 433 \mathrm{pb}$ and $400 \mathrm{bp}$ bands respectively as shown in Figures 2, 3 and 4 respectively. Only aadA2 was absent in isolate 3 . This was indicated by the presence of multiple bands approximately $800 \mathrm{bp}, 200 \mathrm{bp}$ and $287 \mathrm{bp}$ in length corresponding to Tn3bla, GyrA, and ParC genes. 

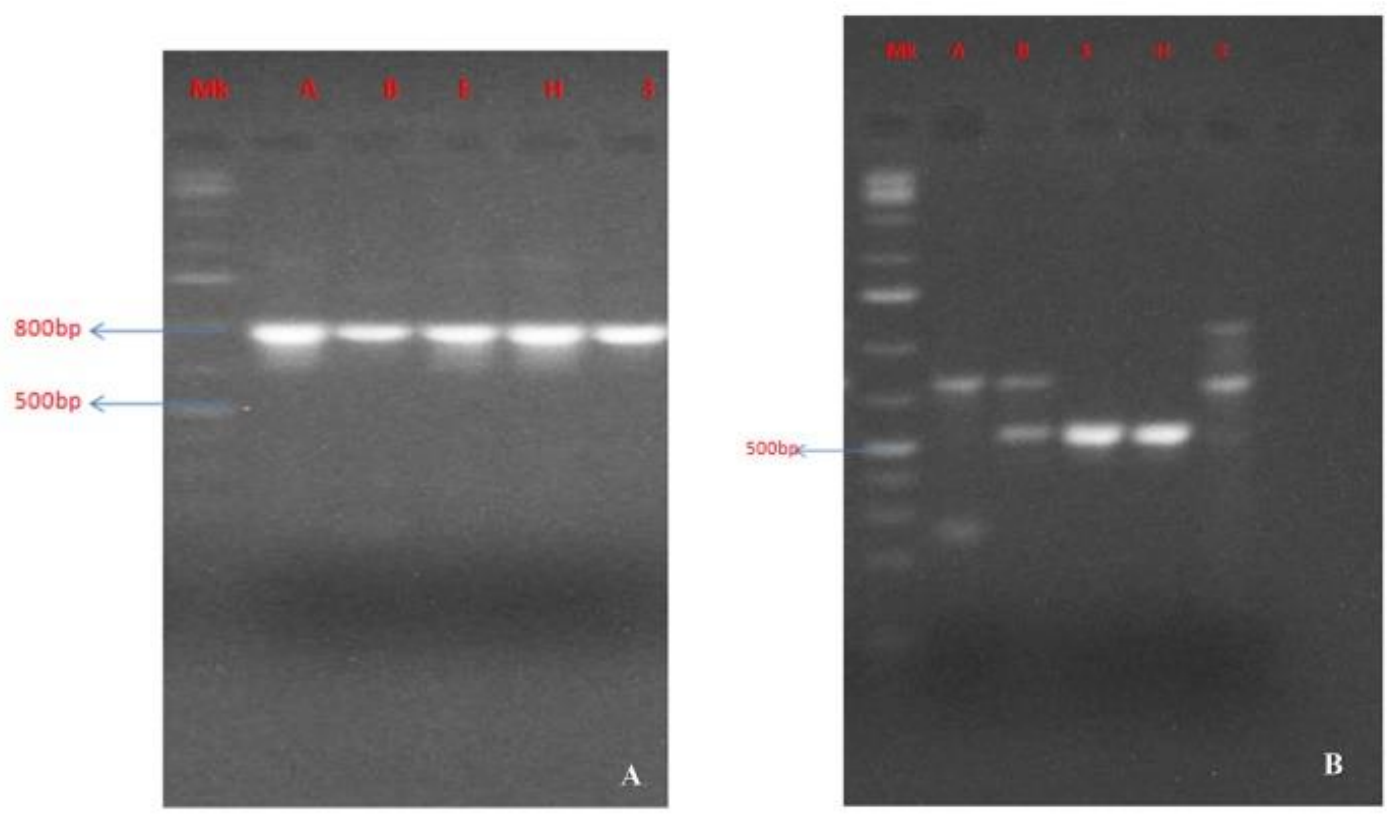

Figure 2: Agarose gel electrophoresis of the amplified antibiotic resistance genes $\mathrm{A}=$ Tn 3 bla; $\mathrm{B}=$ aad $\mathrm{A} 2$
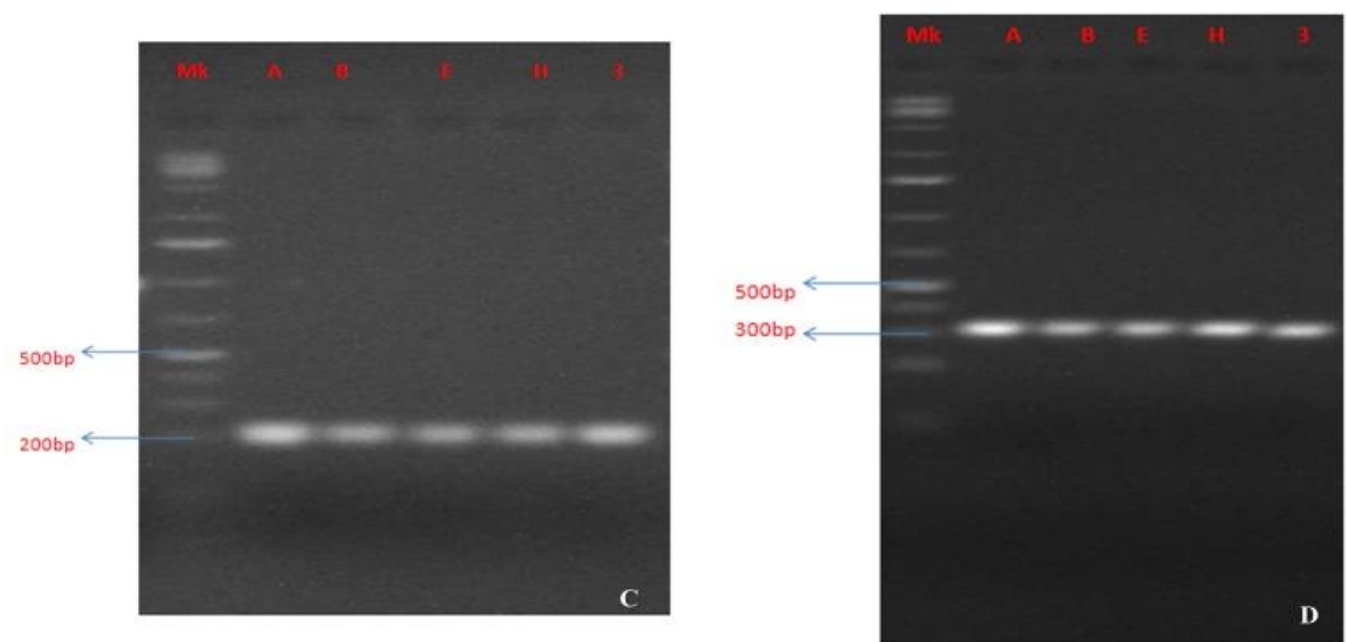

Figure 3: Agarose gel electrophoresis of the amplified antibiotic resistance genes $\mathrm{C}=$ GyrA $\mathrm{D}=$ ParC 


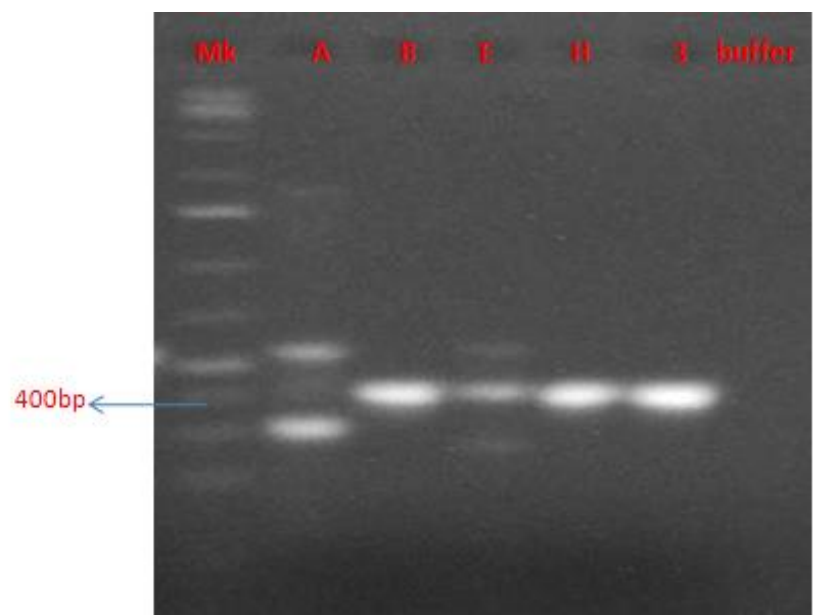

Figure 4: Agarose Gel Electrophoresis of the Amplified Sul1 Antibiotic Resistance Genes

Distribution of antibiotic resistance genes in the selected $E$. coli isolates

The detection of the antibiotic resistance genes in the five (5) selected $E$. coli isolates revealed that $100 \%$ of the isolates had the Tn3bla, GyrA and ParC gene. Similarly, $80 \%$ of the isolates possessed the Sull gene as only 4 isolates were amplified with Sull specific primers. The aadA2 gene had the least occurring because only $60 \%$ of the isolates namely B, E and $\mathrm{H}$ possessed the gene (Table 5).

Table 5: Antibiotic resistance genes in multidrug resistant $E$. coli isolates

\begin{tabular}{|c|c|c|c|c|c|}
\hline $\begin{array}{l}\text { Isolate } \\
\text { code }\end{array}$ & Tn3bla & $\begin{array}{c}\text { Gyr } \\
\text { A }\end{array}$ & $\operatorname{aad} A 2$ & Sul1 & $\begin{array}{c}\text { Par } \\
\text { C }\end{array}$ \\
\hline A & + & + & - & - & + \\
\hline B & + & + & + & + & + \\
\hline $\mathrm{E}$ & + & + & + & + & + \\
\hline $\mathrm{H}$ & + & + & + & + & + \\
\hline 3 & + & + & - & + & + \\
\hline
\end{tabular}

\section{Discussion}

E. coli is the main cause of opportunistic or community acquired infections in humans. ${ }^{15}$ The emergence and increasing rate of MDR E. coli is challenging our ability to treat community acquired infections. This is because $E$. coli can colonize multiple sites in human and animal' bodies, thereby horizontally transmitting or acquiring resistant antimicrobial genes. ${ }^{16}$ The highest number of samples (45/60) positive for $E$. coli observed from $\mathrm{GH}$ could be due to the fact that 
the highest number of samples used for this study was obtained from it as well as the high patronage of this hospital by patients compared to the other study hospitals (Table 2).

The highest phenotypic resistance observed against ampicillin (38.6\%), ofloxacin $(31.4 \%)$ and amoxicillin/clavulanic acid (31.4\%) suggests the possible abuse and widespread resistance to these agents in the study area. The presence of Tn3bla and gyrA in the phenotypically resistant $E$. coli isolates (Table 5) means the resistance observed can become widespread by any of the available mechanisms. Therefore, the use of these antimicrobials as first line antibiotics in the treatment of infections needs to be discouraged since the prevalence of resistance exceeds $10 \% .{ }^{17}$ The ability of pathogenic isolates of $E$. coli to develop resistance, especially to first line broad spectrum antibiotics amongst the enteric pathogens has been recorded from surveillance studies in Nigeria. ${ }^{18-21}$ The higher resistance to ampicillin corroborates previous studies by Rodriguez et al. ${ }^{18-19}$, where $40.8 \%$ and $74.2 \%$ of their E. coli isolates exhibited resistance to ampicillin. The common use of these broad-spectrum antibiotics for the treatment of infections by clinicians could be the possible explanation for these observations. The sale of these drugs by nonprofessionals in Nigerian communities encourages self-medication, possibly resulting to inappropriate dosage, which no doubt, could be responsible for the pattern of resistance observed in this study.

Of the fifty-five (55) resistant $E$. coli isolates, $58.7 \%$ were resistant to at least 2 or more classes of antibiotics (Table 3). This may be a result of the presence of multiple resistance genes in $E$. coli isolates as observed in this study. Previous reports in Nigeria have highlighted high multidrug resistance in E. coli. Percentages of multidrug resistant E. coli from diarrheal stools in previous reports ${ }^{2,22}$ were $56 \%$ and $69.6 \%$ respectively. Hence, the findings of this study are in line with the previous reported studies in Nigeria.

Analysis of results showed the presence of $\geq 4$ resistance genes in the five $E$. coli isolates with $\geq$ 0.5 MDRI (Table 4). This confirms the phenotypic resistance patterns observed for these isolates. The five (5) E. coli isolates possess Tn3bla, gyra and pac genes. Isolates B, E, 3 and $\mathrm{H}$ had sull gene while only B, E and $\mathrm{H}$ possessed aadA2 gene (Table 5). These genes are known to code for sulfonamide, quinolone, aminoglycoside and penicillin resistance. The detection of these genes in $E$. coli isolates in this study suggests that resistance to these antimicrobials is genetically mediated possibly as a result of long-term use or abuse of these antimicrobials. ${ }^{2}$ The presence of Tn3bla, GyrA and Pac in all the studied E. coli isolates agrees with the reports of Momtaz et al ${ }^{6}$ who reported that the possession of these resistant genes confer resistance to the penicillin and quinolones groups of antibiotics.

Reports of antibiotic resistant genes found in $E$. coli isolates might serve as a pointer to the possible presence of other drug resistant genes conferring resistance to other classes of antibiotics that were not targeted in this study. The use of antibiotics in poultry farming, poverty and illiteracy are factors that encourage indiscriminate use of antibiotics and the increasing trend of using leftover drugs ${ }^{23}$ could be the possible explanation for the emergence of multidrug resistance genes.

\section{Conclusion}


Based on the findings of this study, ciprofloxacin and perfloxacin are the most effective against Escherichia coli isolated from Minna, Nigeria. Resistant genes, Tn3bla, GyrA, ParC, aadA2 and Sull coding for penicillin, quinolone, aminoglycoside and sulfonamide resistance are present in $E$. coli isolates from Minna, Nigeria and are responsible for the multidrug resistance observed in isolates.

\section{References}

1. Centers for Disease Control and Prevention CDC (2019). Antibiotic/Antimicrobial Resistance (AR/AMR). https://www.cdc.gov/drugresistance?about.html. accessed 7 September 2019

2. Adenipekun EO, Jackson CR, Ramadan H, et al. Prevalence and multidrug resistance of Escherichia coli from community-acquired infections in Lagos, Nigeria. J Infect Dev Ctries. 2016; 10(9): 920-31 doi: http://dx.doi.org/10.3855/jidc.7997.

3. Zhang P, Wang J, Wang X, et al. Genome sequencing and characterization of five Escherichia coli co-expressing ESBL and MCR-1 resistance mechanisms, from different origins in China. Front. Microbiol. 2019; 10:1994 doi: https://doi.org/10.3389/fmicb.2019.01994

4. Foxman B. The epidemiology of urinary tract infection. Nat Rev Urol, 2010; 7(12): 653-60 doi: http://10.1038/nrurol.2010.190.

5. Kaper JB, Nataro JP, Mobley HL. Pathogenic Escherichia coli. Nat Rev Microbiol, 2004; 2(2):123-40 doi: https://doi.org/10.1038/nrmicro818.

6. Momtaz H, Rahimi E, Moshkelani S. Molecular detection of antimicrobial resistance genes in $E$. coli isolated from slaughtered commercial chickens in Iran. Veterinární Medicína. 2012; 57(4): 193-97 doi: http://dx.doi.org/10.17221/5916-VETMED.

7. WHO. (2018). Escherichia coli.https://www.who.int/news-room/fact-sheets/detail/e-coli accessed 23 October, 2018

8. Larsson DJ, Andremont A, Bengtsson-Palme J, et al. Critical knowledge gaps and research needs related to the environmental dimensions of antibiotic resistance. Environ Int, 2018; 117: 132-38 doi: http://doi.org/10.1016/j.envint.2018.04.041.

9. MacDougall, C. (2018). Penicillins, cephalosporins, and other $\beta$-lactam antibiotics. In: Goodman and Gilman's the pharmacological basis of therapeutics (13th ed). New York, NY: McGraw-Hill, 1023-38.

10. Cheesebrough, M (2006). District Laboratory Practice in Tropical Countries, Part 2 Second Edition. Cambridge University Press United States of America.

11. CLSI. M100-S22: performance standards for antimicrobial susceptibility testing; twentysecond informational supplement M100S22E.pdf. http://www.antimicrobianos.com.ar/ATB/wpcontent/uploads/2012/11/M100S22E.pdf. accessed 22 Dec 2015.

12. Liberto MC, Matera G, Quirino A, et al. Phenotypic and genotypic evaluation of slime production by conventional and molecular microbiological techniques. Microbiological Research. 2009; 29;164(5):522-28 doi: https://doi.org/10.1016/j.micres.2007.04.004.

13. Luo R, Sickler J, Vahidnia F. Use of PCR for diagnosis of Group A Streptococcal pharyngitis in the United States, 2011-2015. Open Forum Infect Dis. 2017; 4(S1): S618 doi: https://doi.org/10.1093/ofid/ofx163.1630.

14. Frank, J. A., Reich, C. I., Sharma, S., et al. Critical evaluation of two primers commonly used for amplification of bacterial 16S rRNA genes. Applied and Environmental Microbiology, 2008; 74(8), 2461-70. No doi

15. Levy SB, Marshall B. Antibacterial resistance worldwide: causes, challenges and responses. Nat Med. 2004; 10:S122-29 doi: https://doi.org/10.1038/nm1145

16. Pitout JD. The latest threat in the war on antimicrobial resistance. Lancet Infect Dis, 2010; 10(9): 578-79 doi: http://dx.doi.org/10.1016/S1473-3099(10)70168-7. 
17. Gupta K, Hooton TM, Naber KG, et al. International clinical practice guidelines for the treatment of acute uncomplicated cystitis and pyelonephritis in women: Clin Infect Dis. 2011; 52(5): e10320 doi: http://dx.doi.org/10.1093/cid/ciq257.

18. Rodríguez H, Fraga R, Gonzalez T, et al. Genetics of phosphate solubilization and its potential applications for improving plant growth-promoting bacteria. Plant and Soil, 2006; 287:15-21. doi: https://doi.org/10.1007/s11104-006-9056-9

19. Yüksel S, Öztürk B, Kavaz A, et al. Antibiotic resistance of urinary tract pathogens and evaluation of empirical treatment in Turkish children with urinary tract infections. Int. J. Antimicrob. Agents. 2006; 28(5):413-16 doi: https://doi.org/10.1016/j.ijantimicag.2006.08.009.

20. Nkang O, Okonko IO, Mejeha OK, et al. Assessment of antibiotics susceptibility profiles of some selected clinical isolates from laboratories in Nigeria. Journal of Microbiology and Antimicrobials, 2009; 1(2):19-26. No doi

21. Akingbade O, Balogun S, Ojo D, et al. Resistant plasmid profile analysis of multidrug resistant Escherichia coli isolated from urinary tract infections in Abeokuta, Nigeria. Afr Health Sci. 2014; 14(4): 821-28 doi: http://dx.doi.org/10.4314/ahs.v14i4.8.

22. El Metwally HA, Ibrahim HA, El-Athamna MN, Amer MA. Multiplex PCR for detection of diarrheagenic Escherichia coli in Egyptian children. J. Med. Sci. 2007 Feb 15; 7(2):255-62 doi: http://10.3923/jms.2007.255.262.

23. Bashir MF, Qazi JI, Ahmad N, et al. Diversity of urinary tract pathogens and drug resistant isolates of Escherichia coli in different age and gender groups of Pakistanis. Trop J Pharm Res 2008; 7(3):1025-31 doi: http://dx.doi.org/10.4314/tjpr.v7i3.14687. 